\title{
Footwear Usage in Children with Flatfoot Disorder in Sukajadi Sub-district, Bandung
}

\author{
Wulan Mayasari, ${ }^{1}$ Elta Sholihah Putri, ${ }^{2}$ Fathurachman ${ }^{3}$ \\ ${ }^{1}$ Department of Biomedical Science Faculty of Medicine Universitas Padjadjaran, Indonesia, \\ ${ }^{2}$ Faculty of Medicine Universitas Padjadjaran Indonesia, ${ }^{3}$ Department of Orthopaedic and \\ Traumatology Faculty of Medicine Universitas Padjadjaran/Dr. Hasan Sadikin General Hospital \\ Bandung Indonesia
}

\section{Abstract}

Background: Flatfoot is a musculoskeletal disorder of the foot where the medial longitudinal arch becomes flatter, resulting in a more foot surface touching the ground compared to the normal foot. One of the risk factors for flatfoot is the rather early footwear usage with a considerably long period of usage with the enclosed footwear type. This may cause weakening of supporting tissues of the foot. This study aimed to describe the use of footwear in children with flatfoot.

Methods: This study used a descriptive categorical method, conducted from March to June 2017 among students from five elementary schools in Sukajadi sub-district, Bandung. Primary data were obtained by using questionnaires and descriptively presented.

Results: Prevalence of flatfoot among included students (n73) of the elementary school with age range of $6-10$ years was $54.8 \%$. All students had their first years of wearing footwear in the age range $0-5$ years. The majority ( $52.5 \%$ ) of footwear usage duration in flatfoot disorder was $\geq 8$ hours/day, and the footwear type of flatfoot disorder was dominated (65\%) by sandals/slippers.

Conclusions: There is a high number of flatfoot in elementary school, and this needs special attention, especially on how to use the footwear.

Keywords: Flatfoot, footwear, medial longitudinal arch

\section{Introduction}

Viewed from the standpoint of biomechanics, the foot has a very complex structure with 26 skeletal elements and many ligaments, tendons, intrinsic and extrinsic muscles, as well as functions that are essential for running, giving more power to withstand the weight and do the movements. The foot is a very important part of the body. ${ }^{1}$ About $90 \%$ of the clinical visit has noted that the biggest cause of foot problems is due to flatfoot. Flatfoot is a disorder of the lower extremities that often occurs in children. ${ }^{2}$ A study conducted toward 1158 respondents of all school students from Babol shows that $16.1 \%$ have flatfoot. ${ }^{3}$ Although flatfoot rarely causes pain, but many parents believe that flatfoot can cause the problem of walking in the future, therefore, the problem of flatfoot is still the focus in most parents. $^{2}$

Flatfoot is a medial longitudinal arch (MLA) condition that falls with the entire sole or almost all of it touches the ground. ${ }^{4}$ If the foot arch does not grow normally it will cause injuries to the feet, knees, and back, balance disorders, unstable, complaint easily of fatigue, and also can cause excessive injury and pain. ${ }^{5,6}$ According to the effects of flatfoot, it creates a separate paradigm for some work agencies, especially those which are directly related to physical activities. One of the occupations that most often uses physical activities is the army or police. In this group, physical ability is one test that is quite decide whether a person is fit to become a soldier or a police officer.

Correspondence: Elta Sholihah Putri, Faculty of Medicine Faculty of Medicine Universitas Padjadjaran, Jalan BandungSumedang Km 21, Jatinangor, Sumedang, Indonesia Email: eltaputris@gmail.com 
Especially in Indonesia, the recruits will be tested for the strength of their hand muscles, abdominal muscles, and the strength of leg muscles to run twelve minutes to depict the distance that can be reached, and a shuttle run which involves running around the shape of the number eight as many as three times that require extra speed. Frequently, flatfoot sufferers are disqualified for military service because they are easily tired when walking or running for long periods. ${ }^{7}$

Furthermore, flatfoot is a physiological condition, especially in neonates. In neonates, there is a fat pad under the medial longitudinal arch. As we get older, these fat pads begin to decrease and the prevalence of flatfoot decreases. On the other hand, the number of flatfoot cases is increased in children who have weak ligaments due to the early use of footwear for long-term use, and the type of closed footwear such as shoes. The use of shoes can limit the leg muscles movement resulting in the flattened arches and thus making leg muscles become weak. ${ }^{2,4}$

Sukajadi is one of the urban areas where most of the population wear various types of footwear and duration of usage, the risk factors for the flatfoot. A systematic study conducted in India has shown that the incidence of flatfoot in urban communities is higher, and the footwear use is associated with increased risk of flatfoot. There is a strong tendency between footwear statuses with the number of flatfoot prevalence; therefore this study aimed to describe the use of footwear in children with flatfoot in Sukajadi sub-district.

\section{Methods}

This study was carried out by using descriptive categorical methods to describe the use of footwear in children with flatfoot. This study was part of previous research in 2017, exploring the prevalence of flat foot in Sukajadi sub-district.

Students from five elementary schools in Sukajadi sub-district, Bandung aged range 6-10 years old were included. This study was conducted from March to June 2017. To collect data, the research instrument used was the questionnaire, distributed to the selected randomly proportional students to be filled by their parents, prior informed consent. The questionnaire assessed the first age of footwear usage $(0-5$ years and $\geq 6$ years $)$, the duration of footwear usage $(<8$ hours and $\geq 8$ hours), and the type of footwear (slippers/ sandals and shoes).
Students who had an incomplete questionnaire and had burned, fractures in the leg region, as well as congenital deformities were excluded.

Flatfoot was defined as a musculoskeletal disorder of the foot where the medial longitudinal arch became flatter, resulting in a more foot surface touching the ground compared to the normal foot. The flatfoot was designated when the arch index of footprint analysis was measured by using the foot stamp printed on paper. The result of footprint analysis waw calculated into thearch index ratio. The normal range ratio of the foot arch index is $0.21-0.28$; whereas the ratio $>0.28$ was designated as flatfoot. The data were presented descriptively in the form of tables.

This research was approved by the Health Research Ethics Committee of Faculty of Medicine of Universitas Padjadjaran (no. 376/ UN6.C.10/PN/2017) and research permit from Dinas Pendidikan Kota Bandung.

\section{Results}

Out of 73 students, mostly were flatfoot (n 40; $54.8 \%$ ) of whom flatfoot was predominantly among girls (60.3\%). All students had worn footwear at age 0-5years. The majority of the students $(52.1 \%)$ had worn footwear for $\geq 8$ hours/day. The type of footwear (67.1\%) preferred to wear was slippers (Table 1).

All students had the first age group wearing footwear for flatfoot patients was by the $0-5$ age group. However, based on the footwear duration of flatfoot patients, almost $52.5 \%$ were wearing footwear for $\geq 8$ hours/day. The type of footwear used by flatfoot children was slippers with a proportion of $65 \%$ (Table 1).

\section{Discussions}

This study was conducted to describe the use of footwear in children with flatfoot in Sukajadi sub-district. In this study, the flatfoot prevalence obtained from elementary students in the Sukajadi sub-district is 54.8\%. This study is in accordance with the study in India that shows flatfoot incidence is higher in the urban community. Footwear is often implicated in orthopedic problems which can affect the lower limb and back. ${ }^{8}$ Individuals who are wearing shoes before six years old and with the wearing a duration of more than eight hours per day at an early age have significantly higher flatfoot prevalence compared to the others who are wearing footwear for a shorter duration. This report is same as the data 
Table 1 Characteristic of the Students from Elementary Schools in Sukajadi sub-district, Bandung

\begin{tabular}{|c|c|c|c|}
\hline & Normal Foot & Flatfoot & Total \\
\hline & $(\mathrm{N}=33)$ & $(\mathrm{N}=40)$ & $(\mathrm{N}=73)$ \\
\hline \multicolumn{4}{|l|}{ Gender, n (\%) } \\
\hline Boys & $12(36.4)$ & $17(42.5)$ & 29 (39.7) \\
\hline Girls & $21(63.6)$ & $23(57.5)$ & $44(60.3)$ \\
\hline \multicolumn{4}{|l|}{ Age, $n(\%)$} \\
\hline 6 years old & $1(3.0)$ & - & $1(1.4)$ \\
\hline 7 years old & $4(12.1)$ & $6(15)$ & 10 (13.7) \\
\hline 8 years old & $6(18.2)$ & $9(22.5)$ & $15(20.5)$ \\
\hline 9 years old & $10(30.3)$ & $16(40)$ & $26(35.6)$ \\
\hline 10 years old & $9(27.3)$ & $12(30)$ & $21(28.8)$ \\
\hline \multicolumn{4}{|c|}{ The first age group of wearing footwear, $n(\%)$} \\
\hline $0-5$ years old & $33(100)$ & $40(100)$ & $100(100)$ \\
\hline$\geq 6$ years old & - & - & - \\
\hline \multicolumn{4}{|c|}{ Footwear duration, $\mathrm{n}(\%)$} \\
\hline$<8$ hours/day & $16(48.5)$ & $19(47.5)$ & $35(47.9)$ \\
\hline$\geq 8$ hours/day & $17(51.5)$ & $21(52.5)$ & $38(52.1)$ \\
\hline \multicolumn{4}{|c|}{ Type of footwear, n(\%) } \\
\hline Sandal/slippers & $23(69.7)$ & $26(65)$ & $49(67.1)$ \\
\hline Shoes & $10(30.3)$ & $14(35)$ & $24(32.9)$ \\
\hline
\end{tabular}

obtained in our study. The main function of footwear is to protect the foot from scrapes or injury of harmful objects. Along with the times, footwear has been produced in various shapes. The urban area is the area most exposed to new trends, and mode in the shoes industry. This may support the result of our study, showing that all children started to wear footwear for the first time at age $0-5$ years, with the wearing duration of $\geq 8$ hours. ${ }^{4}$

In the another study carried out among children in urban and rural communities of Southwest Nigeria, all children in the urban area have used closed footwear, while most of the children in the rural area (69.5\%) have used other forms of footwear. ${ }^{4}$ Interestingly, there is a significant escalation of flatfoot prevalence in children who are wearing shoes and who do not. This indicates that closed footwear can increase flatfoot prevalence. However, our study has shown a different trend, indicating that $65 \%$ of children with flatfoot syndrome is dominated by slippers usage. This different in result may probably due to the usage of slippers that is easier to wear and more practical for daily activities.

In general, human foot bones have an arch, which can give more power for foot endurance and stability during the movements. There are musculoskeletal disorders on foot among others flatfoot, of which the medial longitudinal arch on foot become flat, resulting in a more surfaces tread of the foot on the floor. ${ }^{9}$ Flatfoot may affect in one foot or both feet, that not only increases the load acting on foot structure, but it also can interfere the normal foot function. ${ }^{10}$ There are several techniques to evaluate foot structure and to diagnose flatfoot such as clinical diagnosis, X-Ray studies, visual observation, footprint analysis that measure the frontal plane heel position and assess the position of the navicular tuberosity. Foot radiographs and computed tomography (CT) are the most useful method for analysis of the complex tarsal bones. ${ }^{11-13}$

The cause of flatfoot includes obesity, posture abnormality, neurology and muscular abnormality, a genetic condition, collagen disorders, and the weakness of supporting tissue. ${ }^{2}$ The fat pads may resolve between the 
ages of 2 and 5 years as the arch of the foot developed. ${ }^{2}$ By wearing footwear at age under six and with wearing duration more than eight hours per day, especially with the use closed footwear such as shoes, these factors can damage the arch development and will affect the occurrence of flatfoot. ${ }^{4}$

The limitation of this study was the recall bias of the parent's memory to remember when their children wearing footwear. Moreover, this study only describes the footwear status of flatfoot and its results could not show the effect of footwear usage on the increasing number of flatfoot prevalence. Analytical studies on a cohort prospective study should be suitable to identify the correlation between the usage of footwear with the number of flatfoot prevalence by considering various factors that are associated with flatfeet, such as different activities, body mass index, and genetic factors to get more accurate results.

In conclusion, the flatfoot prevalence in our study among elementary students aged 6-10 years is approximately $54.8 \%$, of which the first time of footwear usage at age 0-5 years and with duration for $\geq 8$ hours/day, dominated by slippers users. The high number of flatfoot in the elementary school needs special attention, especially on how to use the footwear.

\section{References}

1. D’Aout K, Pataky TC, De Clercq D, Aerts P. The effects of habitual footwear use: foot shape and function in native barefoot walkers. Footwear Sci. 2009;1(2):81-94.

2. Halabchi F, Mazaheri R, Mirshahi M, Abbasian L. Pediatric flexible flatfoot; clinical aspects and algorithmic approach. Iran J Pediatr. 2013;23(3):247-60.

3. Pourghasem $M$, Kamali N, Farsi $M$, Soltanpour N. Prevalence of flatfoot among school students and its relationship with BMI. Acta Orthop Traumatol Turc. 2016;50(5):554-7.

4. Abolarin T, Aiyegbusi A, Tella A, Akinbo S. Predictive factors for flatfoot: the role of age and footwear in children in urban and rural communities in South West Nigeria. Foot (Edinb). 2011;21(4):188-92.

5. Tashiro $Y$, Fukumoto $T$, Uritani D, Matsumoto D, Nishiguchi S, Fukutani N, et al. Children with flat feet have weaker toe grip strength than those having a normal arch. J Phys Ther Sci. 2015;27(11):3533-6.

6. Herianto $\mathrm{H}$, Aminoto B. Analisis pengaruh bentuk telapak kaki terhadap kelelahan fisik. Jurnal Teknosains. 2013;2(2):71158.

7. Dinas Penerangan Tentara Nasional Indonesia Angkatan Darat. Pembukaan Taruna Akmil. Jakarta Pusat: TNI Angkatan Darat; 2014. [cited 2017 October 15]. Available from:https://tniad.mil. id/2014/03/pembukaan-taruna-akmil/

8. Kurup HV, Clark CI, Dega RK. Footwear and orthopaedics. Foot Ankle Surg. 2012;18(2):79-83.

9. Lendra Made Dody, Santoso Totok Budi. Beda pengaruh kondisi kaki datar dan kaki dengan arkus normal terhadap keseimbangan statis pada anak usia 8-12 tahun di Kelurahan Karangasem, Surakarta. Jurnal Fisioterapi. 2009;9(2):49-58.

10. Bok SK, Lee H, Kim BO, Ahn S, Song Y, Park I. The effect of different foot orthosis inverted angles on plantar pressure in children with flexible flatfeet. PloS One. 2016;11(7):e0159831.

11. Fernandez SP, Martin CG, Pillado TS, Calvino BL, Diaz SP, Gil Guillen V. Validity of footprint analysis to determine flatfoot using clinical diagnosis as the gold standard in a random sample aged 40 years and older. J Epidemiol. 2015;25(2):148-54.

12. Menz HB, Fotoohabadi MR, Wee E, Spink MJ. Visual categorisation of the arch index: a simplified measure of foot posture in older people. J Foot Ankle Res. 2012;5;10.

13. Kido M, Ikoma K, Hara Y, Imai K, Maki $\mathrm{M}$, Ikeda $\mathrm{T}$, et al. Effect of therapeutic insoles on the medial longitudinal arch in patients with flatfoot deformity: a three-dimensional loading computed tomography study. Clin Biomech (Brsitol, Avon). 2014;29(10):1095-8. 